\title{
Oncolytic vaccinia virus GLV-1h68 strain shows enhanced replication in human breast cancer stem-like cells in comparison to breast cancer cells
}

Huiqiang Wang ${ }^{1,2}$, Nanhai G Chen ${ }^{2,3}$, Boris R Minev ${ }^{2,3,4}$ and Aladar A Szalay ${ }^{1,2,3,5^{*}}$

\begin{abstract}
Background: Recent data suggest that cancer stem cells (CSCs) play an important role in cancer, as these cells possess enhanced tumor-forming capabilities and are responsible for relapses after apparently curative therapies have been undertaken. Hence, novel cancer therapies will be needed to test for both tumor regression and CSC targeting. The use of oncolytic vaccinia virus (VACV) represents an attractive anti-tumor approach and is currently under evaluation in clinical trials. The purpose of this study was to demonstrate whether VACV does kill CSCs that are resistant to irradiation and chemotherapy.
\end{abstract}

Methods: Cancer stem-like cells were identified and separated from the human breast cancer cell line GI-101A by virtue of increased aldehyde dehydrogenase 1 (ALDH1) activity as assessed by the ALDEFLUOR assay and cancer stem cell-like features such as chemo-resistance, irradiation-resistance and tumor-initiating were confirmed in cell culture and in animal models. VACV treatments were applied to both ALDEFLUOR-positive cells in cell culture and in xenograft tumors derived from these cells. Moreover, we identified and isolated $\mathrm{CD} 44^{+} \mathrm{CD} 24^{+} \mathrm{ESA} \mathrm{A}^{+}$cells from GI-101A upon an epithelial-mesenchymal transition (EMT). These cells were similarly characterized both in cell culture and in animal models.

Results: We demonstrated for the first time that the oncolytic VACV GLV-1h68 strain replicated more efficiently in cells with higher ALDH1 activity that possessed stem cell-like features than in cells with lower ALDH1 activity. GLV-1h68 selectively colonized and eventually eradicated xenograft tumors originating from cells with higher ALDH1 activity. Furthermore, GLV-1h68 also showed preferential replication in CD44 ${ }^{+} \mathrm{CD} 24^{+} \mathrm{ESA}{ }^{+}$cells derived from GI-101A upon an EMT induction as well as in xenograft tumors originating from these cells that were more tumorigenic than $\mathrm{CD}_{4} 4^{+} \mathrm{CD} 24^{-} \mathrm{ESA} \mathrm{A}^{+}$cells.

Conclusions: Taken together, our findings indicate that GLV-1h68 efficiently replicates and kills cancer stem-like cells. Thus, GLV-1h68 may become a promising agent for eradicating both primary and metastatic tumors, especially tumors harboring cancer stem-like cells that are resistant to chemo and/or radiotherapy and may be responsible for recurrence of tumors.

Keyword: Aldehyde dehydrogenase 1, Cancer stem cells, Oncolytic virotherapy, Vaccinia virus, EMT

\footnotetext{
* Correspondence: aaszalay@genelux.com

${ }^{1}$ Institute of Biochemistry, Biocenter, University of Würzburg, Am hubland,

D-97074, Würzburg, Germany

${ }^{2}$ Genelux Corporation, San Diego Science Center, 3030 Bunker Hill Street,

Suite 310, San Diego, CA 92109, USA

Full list of author information is available at the end of the article
} 


\section{Background}

There is an increasing body of knowledge that human breast cancers are driven by a tumor-initiating "cancer stem cells" (CSCs) component that may contribute to tumor metastases and therapeutic resistance [1-5]. Breast CSCs were initially characterized as CD $44^{+} / \mathrm{CD} 24^{-} / \mathrm{lin}^{-}$ cells that were capable of serial transplantation in nonobese/severe combined immunodeficient (NOD/SCID) mice [6]. In addition to these markers, Ginestier et.al have recently shown that cells with stem cell properties in both normal and malignant breast samples can be identified by the expression of the enzyme aldehyde dehydrogenase 1 (ALDH1). By using flow cytometry and the ALDEFLUOR assay that measures ALDH1 activity, CSCs were isolated from primary human mammary carcinomas grown as xenografts in NOD/SCID mice. In addition, ALDH1 immunostaining identified both normal and malignant stem cells in situ in fixed paraffin embedded sections [7]. Furthermore, recent data suggests that immortalized cell lines derived from both murine and human tissues may also contain a cellular population displaying stem cell properties [8-11]. By analyzing thirty-three breast cancer cell lines, Charafe-Jauffret et al. confirmed the hierarchical organization of immortalized cell lines and identified ALDH1 as a potential stem cell marker and therapeutic target [12].

Recently, the involvement of an Epithelial-Mesenchymal Transition (EMT) in the metastatic dissemination of epithelial cancer cells has emerged in cancer biology as a novel concept. Using a mammary tumor progression model, it was shown that cells possessing both stem and tumorigenic characteristics of CSCs can be derived from human mammary epithelial cells following the activation of the Ras-MAPK pathway and that the acquisition of stem and tumorigenic characters is driven by EMT induction $[13,14]$. Moreover, the EMT cell model has successfully been utilized for screening for agents with mammary epithelial CSCs-specific toxicity [15].

Advances in cancer research has resulted in increased detection, improved treatments and enhanced prevention of metastases. Despite these advances, however, metastatic cancers are generally resistant to conventional therapeutics and the prognosis is poor. Therefore, there is an urgent need for the development of new therapies and novel approaches which target cancer metastases. A growing body of scientific evidence indicates that oncolytic vaccinia viruses (VACVs) carrying imaging genes may represent a new treatment strategy that combines tumor site-specific therapeutics with diagnostics (theranostics) [16].

The human breast cancer cell line GI-101A was widely used as a model for testing oncolytic VACV theranostics in our groups [17-24]. To demonstrate the efficacy of vaccinia virotherapy against cancer stem-like cells, we isolated ALDEFLUOR-positive and ALDEFLUOR-negative cells from GI-101A cells and applied the viral treatment to these cells. The evidence from cell culture and tumor xenograft studies indicated that GI-101A-derived ALDEFLUORpositive cells possessed CSC properties. Compared to ALDEFLUOR-negative cells, the oncolytic VACV GLV-1h68 strain showed enhanced replication in the ALDEFLUORpositive cells and was also able to eradicate the xenograft tumors derived from ALDEFLUOR-positive cells. Moreover, we isolated $\mathrm{CD} 44^{+} \mathrm{CD} 24^{+} \mathrm{ESA}^{+}$and $\mathrm{CD} 44^{+} \mathrm{CD} 24^{-} \mathrm{ESA}^{+}$ cells from GI-101A cell line upon an EMT induction. The $\mathrm{CD} 44^{+} \mathrm{CD} 24^{+} \mathrm{ESA}^{+}$cells demonstrated increased tumorigenicity than $\mathrm{CD} 44^{+} \mathrm{CD} 24^{-} \mathrm{ESA}^{+}$cells. Interestingly, GLV-1h68 strain showed enhanced replication in $\mathrm{CD}_{4} 4^{+} \mathrm{CD} 24^{+} \mathrm{ESA}^{+}$cells in contrast to $\mathrm{CD} 44^{+} \mathrm{CD} 24 \mathrm{ESA}^{+}$ cells and better therapeutic efficacy in the xenograft tumors derived from the $\mathrm{CD} 44^{+} \mathrm{CD} 24^{+} \mathrm{ESA}^{+}$cells.

\section{Methods}

\section{Cell culture}

Human breast cancer cell lines (MCF-7, MDA-MB-231, and HS578T) and African green monkey kidney fibroblasts $(\mathrm{CV}-1)$ were obtained from the American Type Culture Collection (ATCC). SUM149PT was purchased from Asterand, PLC (Detroit, MI). The cell line GI-101A, a highly metastatic derivative of GI-101 human ductal adenocarcinoma [25-27], was kindly provided by Dr. A. Aller (Rumbaugh-Goodwin Institute for Cancer Research, Inc.). The cell lines were grown under the recommended culture conditions (Additional file 1: Table S1, Additional file 2: Figure S2). All experiments were done with semi-confluent cells in the exponential phase of growth. Immortalized human mammary epithelial cells (HMLE) were kindly provided and cultured as recommended by Dr. R.A. Weinberg (Whitehead Institute, Cambridge, MA). HMLE were cultured in 1:1 Dulbecco's Modified Eagle's Medium (DMEM)/F12 medium (Cellgro) complemented with 10\% FBS (Cellgro), $100 \mathrm{U} / \mathrm{ml}$ penicillin-streptomycin (Cellgro), $2 \mathrm{mM} / \mathrm{L}$ glutamine (Cellgro), $10 \mathrm{ng} / \mathrm{ml}$ human epidermal growth factor (EGF) (Stemgent), $0.5 \mathrm{mg} / \mathrm{ml}$ hydrocortisone (Lonza) and $10 \mathrm{mg} / \mathrm{ml}$ insulin (Sigma). EMT was induced with additional $10 \mathrm{ng} / \mathrm{ml}$ recombinant human transforming growth factor (TGF- $\beta 1$ ) (Stemgent) for 12 days. Similar culture condition was utilized to induce EMT in GI-101A cells.

\section{ALDEFLUOR assay and isolation of the ALDEFLUOR-positive cell population by fluorescence-activated cell sorting}

ALDH1 activity was assessed in five human breast cancer cell lines using the ALDEFLUOR kit (StemCell Technologies). The population with higher ALDH1 enzymatic activity was isolated using a FACSAria ${ }^{\mathrm{Tm}}$ III (Becton Dickinson), as previously described [7], and analyzed using Cell Lab Quanta $^{\text {TM }}$ SC MPL (Beckman Coulter). Briefly, $1 \times 10^{6}$ cells 
were incubated in $1 \mathrm{ml}$ ALDEFLUOR assay buffer containing ALDH1 substrate $\left(1 \times 10^{-6} \mathrm{M}\right)$. In each experiment, a sample of cells was stained under identical conditions in the presence of $50 \mathrm{mM}$ diethylaminobenzaldehyde, a specific ALDH1 inhibitor, as a negative control. The electronic sorting gates were set to exclude dead cells, doublets and aggregates. After sorting, the purity of sorted populations was examined using a double sorting of 10,000 ALDEFLUOR-positive and ALDEFLUOR-negative cells. The sorted ALDEFLUOR-positive population contained $>80 \%$ of ALDEFLUOR-positive cells. On contrast, no ALDEFLUOR-positive cells were detected in the ALDEFLUOR-negative population.

\section{EMT induction assay and isolation of the $\mathrm{CD} 44^{+} \mathrm{CD} 24^{+} \mathrm{ESA}^{+}$ population by fluorescence-activated cell sorting}

For EMT induction, HMLE and GI-101A cell lines were treated with EGF and TGF- $\beta 1$ as described previously. The immunostaining was performed using the following antibodies against EMT markers: anti-E-cadherin (clone 36) (BD Transduction Laboratories), anti-Vimentin (clone V9) (Sigma) and anti-Fibronectin (clone 10) (BD Transduction Laboratories). Identification and sorting of $\mathrm{CD} 44^{+} \mathrm{CD} 24^{+} \mathrm{ESA}^{+}$and $\mathrm{CD} 44^{+} \mathrm{CD} 24^{-} \mathrm{ESA}^{+}$were performed using anti-human monoclonal antibodies such as anti-CD44-APC (clone G44-26) (BD Pharmingen), antiCD24-PE (clone ML5) (BD Pharmingen) and anti-ESAFITC (clone VU-1D9) (StemCell Technologies) on a BD FACSAria ${ }^{\text {Tu }}$ III cell sorter as described by the manufacturer.

\section{Flow cytometry}

Nonconfluent cell cultures were trypsinized and the cell concentration was determined. Then the single cell suspension was washed with $1 \times$ DPBS (Mediatech), and stained with antibodies recognizing human cell surface markers such as anti-CD44-APC (clone G44-26) (BD Pharmingen), anti-CD24-FITC (clone ML5) (BD Pharmingen), and anti-CD49f-PE (clone GoH3) (BD Pharmingen). Approximately 10,000 cells were incubated with antibodies for 30 minutes at room temperature according to manufacturer's instructions. The unbound antibodies were washed off and cells were analyzed within 1 hour after staining on a BD FACSAria ${ }^{\mathrm{Tm}}$ III (Becton Dickinson). All flow cytometry data were analyzed by Flowjo software (Treestar).

\section{Animal models and testing for tumorigenicity}

Tumorigenicity of GI-101A ALDEFLUOR-positive and ALDEFLUOR-negative cells or $\mathrm{CD} 44^{+} \mathrm{CD} 24^{+} \mathrm{ESA}^{+}$and $\mathrm{CD}_{4} 4^{+} \mathrm{CD} 24^{-} \mathrm{ESA}^{+}$cells were assessed by measuring the efficiency of tumor formation in the abdominal mammary gland fat pad of 6-8 weeks old athymic nude mice (NCI/ Hsd/Athymic Nude-Foxn $1^{\text {nu }}$, Harlan). After sorting, the limiting dilutions $(50,000,5,000$, and 500 cells) of the
ALDEFLUOR-positive and ALDEFLUOR-negative population or 10,000 and 1,000 cells of $\mathrm{CD} 44^{+} \mathrm{CD} 24^{+} \mathrm{ESA}^{+}$and $\mathrm{CD}_{4} 4^{+} \mathrm{CD} 24 \mathrm{ESA}^{+}$population of GI-101A cells were mixed with Matrigel (BD Biosciences; 1:1) and implanted to the mammary fat pads. Tumor growth was recorded weekly in two dimensions using a digital caliper. Tumor volume was calculated as [(length $\times$ width $\times$ width $) / 2$ ] and reported in cubic millimeter. All animal experiments were conducted in accordance with accepted standards of humane animal care and all experiments were approved by the Animal Care and Use Committee at Explora Biolabs (San Diego Science Center).

\section{Virotherapy of GI-101A ALDEFLUOR or CD44 ${ }^{+} \mathrm{CD} 24^{+} \mathrm{ESA}^{+}$ xenograft tumors with GLV-1h68 strain}

To assess the response of GI-101A tumors derived from ALDEFLUOR-positive and ALDEFLUOR-negative cells and derived from $\mathrm{CD} 44^{+} \mathrm{CD} 24^{+} \mathrm{ESA}^{+}$and $\mathrm{CD} 44^{+} \mathrm{CD} 24^{-} \mathrm{ESA}^{+}$ cells, tumor colonization experiments with retro-orbitally injected GLV-1h68 strain in nude mice were carried out. 12 weeks after implantation of 5,000 ALDEFLUOR sorted cells or 22 weeks after implantation of 10,000 marker-sorted cells, a single dose of GLV-1h68 strains $\left(5 \times 10^{6} \mathrm{pfu}\right.$ in $100 \mu \mathrm{L} 1 \times \mathrm{DPBS}$ ) was retro-orbitally injected into tumorbearing mice. A total of 30 mice, 5 for each dose group, were included in this study. Tumor measurements were recorded weekly for 7 weeks after initial virus injection, in parallel with fluorescence imaging of tumors.

\section{Anchorage-independent culture of tumor cells}

ALDEFLUOR-positive and ALDELFUOR-negative cells from GI-101A were plated as single cells in 96-well ultra-low attachment plates (Corning) at different densities $(1,10$, and 100 viable cells/well). Cells were grown in MammoCult ${ }^{\circledR}$ human medium Kit (StemCell Technologies) for 12 days as described [28]. The capacity of cells to form mammospheres was quantified using ImageJ software (NIH, USA).

\section{Cytotoxicity of drugs in cell cultures}

Fluorouracil (5-FU), cis-Diammine (1, 1-cyclobutanedicarboxylato) platinum (II) (Carboplatin), cis-diamminedichloroplatinum (II) (CDDP) (Cisplatin), Mitomycin $\mathrm{C}$ and Salinomycin were purchased from Sigma Aldrich; 3-(4, 5-Dimethylthiazol-2-yl)2, 5-diphenyltetrazolium bromide (MTT) cellular proliferation assays were used for quantitation of chemo-cytotoxicity as described [18]. ALDEFLUOR-positive and ALDELFUORnegative cells $(50,000)$ from GI-101A were plated in 96well plates in growth medium overnight and, thereafter, in serum-free medium. Cells were exposed to increasing concentrations $\left(10^{-9}, 10^{-8}, 10^{-7}, 10^{-6}, 10^{-5}, 10^{-4} \mathrm{M}\right)$ of drugs (diluted in DMSO) for 96 hours, followed by the removal of media and the addition of $500 \mu \mathrm{L}$ MTT $(2.5 \mathrm{mg} / \mathrm{mL})$ in RMPI without phenol red, for further culturing at $37^{\circ} \mathrm{C}$ and $5 \% \mathrm{CO}_{2}$ for 4 hours. MTT solution was then removed 
and $400 \mu \mathrm{L}$ isopropanol containing $1 \mathrm{~N} \mathrm{HCl}$ was added. The samples $(3 \times 100 \mu \mathrm{L})$ were transferred to a 96-well plate and the absorbance was determined at $570 \mathrm{~nm}$, as well as $650 \mathrm{~nm}$ in a SpectraMax M5 plate reader (Molecular Devices). Cell survival was calculated using the following formula: \% cell survival $=$ (absorbance value of treated cells/absorbance value of untreated control cells $) \times 100 \%$.

\section{Tumor cell sensitivity to irradiation}

For clonogenic assays, ALDEFLUOR-positive and ALDELFUOR-negative cells $\left(10^{5}\right.$ cells $\left./ \mathrm{mL}\right)$ from GI-101A were irradiated at room temperature with a RS $2000 \mathrm{X}$-ray Biological Irradiator (Rad Source Technologies, Inc) at a dose rate of $4.95 \mathrm{~Gy} /$ minute. A dose curve of $0,0.5,1,2$, and 4 Gy was also generated. All controls were sham irradiated. To determine cell survival, colony forming assays were performed immediately after irradiation by plating cells in triplicate into 6-well plates. After a growth period of 28 days, cells were fixed with $75 \%$ ethanol and stained with $1 \%$ crystal violet, and colonies containing more than 50 cells were counted.

\section{Cell invasion assays}

Invasion assays were done using Cultrex ${ }^{\circledR}$ 96-well Basement Membrane Extract (BME) Cell Invasion Assay (Trevigen). Briefly, triplicate transwell chambers with $8-\mu \mathrm{m}$ pore polycarbonate filters were coated with $50 \mu \mathrm{L}$ of icecold 0.5× BME in DMEM/F12 and incubated for one hour at $37^{\circ} \mathrm{C}$. Then cells in $200 \mu \mathrm{L}$ of serum-free medium were added to the upper chamber. To monitor cell migration, 5,000 cells were seeded on the BME-coated filters and the lower chamber was filled with $600 \mu \mathrm{L}$ of medium without or supplemented with $10 \%$ fetal bovine serum (Cellgro). After incubation for 48 hours, the cells on the underside of the filter were quantified by using Calcein-AM according to the assay kit manual.

\section{Viral replication in cell cultures}

Sorted ALDEFLUOR-positive and ALDELFUOR-negative GI$101 \mathrm{~A}$ cells $\left(1 \times 10^{5}\right)$ or $\mathrm{CD} 44^{+} \mathrm{CD} 24^{+} \mathrm{ESA}^{+}$and $\mathrm{CD} 44^{+} \mathrm{CD} 24^{-}$ $\mathrm{ESA}^{+}$cells $\left(1 \times 10^{5}\right)$ were seeded into 24 -well plates in triplicate and were infected with GLV-1h68 strain at an MOI of 10 or 0.01 . The cells were incubated at $37^{\circ} \mathrm{C}$ for 1 hour with brief agitation every 10 minutes to aid infection. Then the infection medium was removed and cells were incubated in fresh growth medium until cell harvest at 1, 12, 24, 48, 72 hours post infection. Viral particles from the infected cells were released by performing a quick freezethaw cycle and the titers determined by plaque assays in CV-1 cell monolayers and recorded as plaque forming units (pfu)/million cells in duplicate. For the infection of EMT cells, HMLE and GI-101A cells were infected with GLV-1h68 or GLV-1h190 strain at an MOI of 10 after 12 day EMT induction. After incubation at $37^{\circ} \mathrm{C}$ for 1 hour, the infection medium was removed and replaced with fresh growth medium. Virus infection was monitored at different time points by taking images of same cells under a fluorescence microscope.

\section{Statistical analysis}

Results are presented as the mean \pm standard deviation, calculated from a minimum of three repeated individual experiments for each group. Statistical analyses were done with SPSS (version 10, SPSS, Inc.). The comparisons among treatment groups were made using ANOVA, and the differences between groups were analyzed using LSD test when the ANOVA showed an overall significance. Statistical analysis of survival time was assessed using the log-rank test. $\mathrm{P}$ values of $<0.05$ were considered significant.

\section{Results}

Isolation and tumorigenicity of ALDEFLUOR-positive, cancer stem-like cells from GI-101A breast cancer cell line The enzyme ALDH1 is a useful marker for isolating healthy human mammary stem cells, progenitor cells as well as transformed tumor-initiating stem cells [12]. The cancer stem-like cells are isolated by virtue of their expression of ALDH1 activity, as assessed by flow cytometry using the ALDEFLUOR assay. To determine whether human breast cancer cell lines contain an ALDEFLUORpositive population, we analyzed five cell lines of GI-101A, MCF-7, MDA-MB-231, Hs 578 T and SUM149PT, using the ALDEFLUOR assay. In each cell line, we identified an ALDEFLUOR-positive fraction in the size of $6.43 \pm 0.98 \%$, $0.28 \pm 0.06 \%, 1.74 \pm 0.35 \%, 1.45 \pm 0.26 \%$ and $18.35 \pm 6.54 \%$ of the total viable cell population, respectively (Additional file 3: Figure S3). We stained adherent GI-101A cells in plates with ALDEFLUOR present or absent of diethylaminobenzaldehyde (DEAB), an inhibitor of ALDH1 to confirm the flow cytometry results. The fluorescent images indicated the presence of ALDEFLUOR-positive cells in GI-101A and treatment with DEAB reduced ALDH1 activity (Additional file 4: Figure S4). We sorted GI-101A cells for the ALDEFLUOR-positive and ALDEFLUORnegative populations (Figure 1A-F) by incubating the cells with a fluorescent ALDEFLUOR substrate BODIPYaminoacetaldehyde (BAAA) and with DEAB, the specific inhibitor of ALDH1 enzyme. The experiment was used to establish the fluorescence baseline of ALDH1- cells and to define the ALDEFLUOR-positive area (ALDH1+) (Figure 1E). We found that incubation of cells with ALDEFLUOR in the absence of DEAB caused a shift in BAAA fluorescence, which defined the ALDEFLUORpositive cell population (Figure 1D). ALDH1+ and ALDH1 - cells were separated under sterile conditions in order to test the tumorigenic potential of GI-101A ALDEFLUOR-positive cells in nude mice mammary fat pad xenografts and in cell culture by mammosphere 


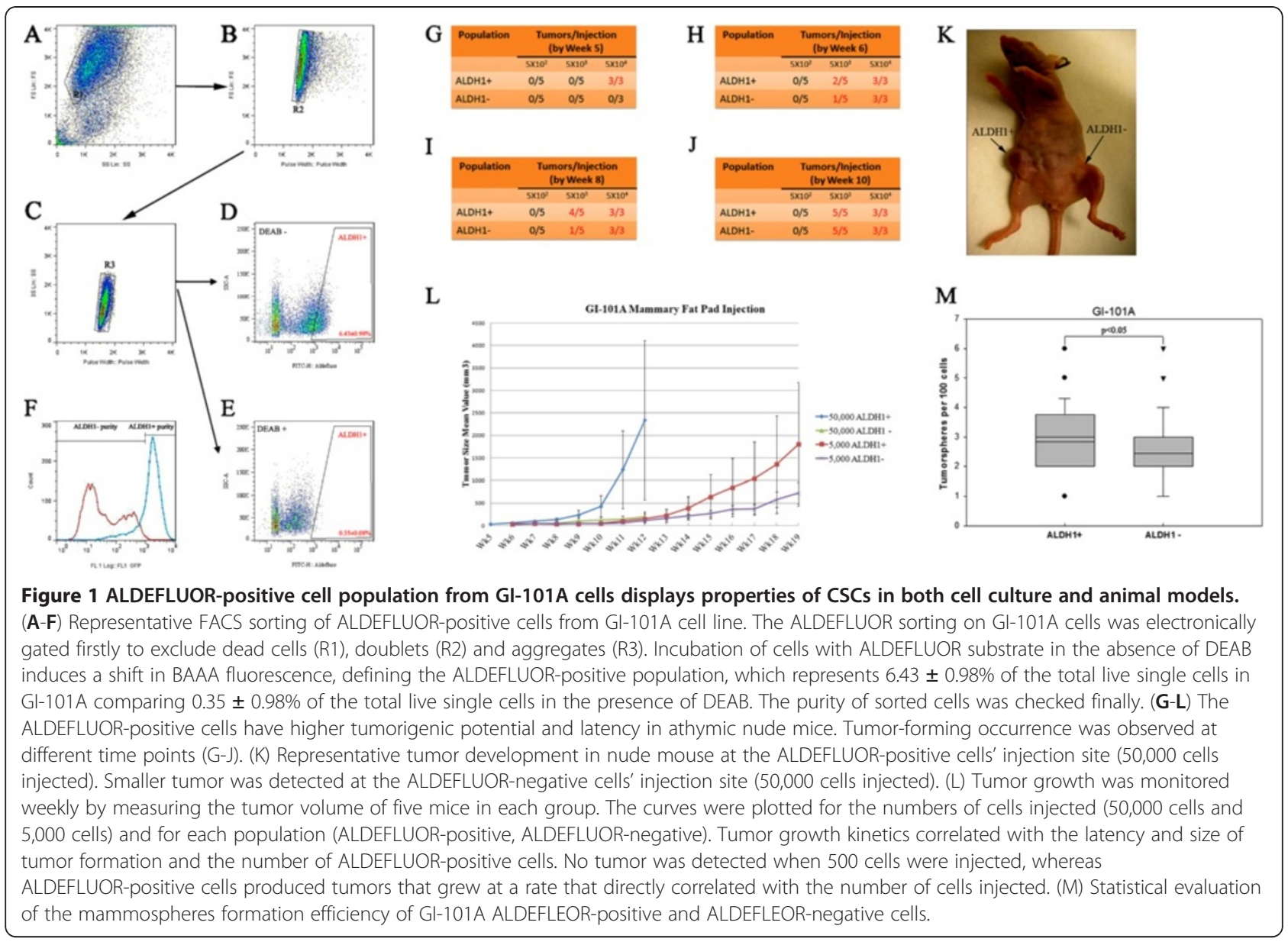

formation assay. The tumorigenicity of the ALDEFLUORpositive and ALDEFLUOR-negative cells from GI-101A were tested by inoculating escalating doses of cells (500, 5,000 , and 50,000 cells) into mammary fat pads of nude mice. Tumors were detected in mice injected with 50,000 ALDEFLUOR-positive cells as early as five weeks after cell implantation (Figure 1G). ALDEFLUOR-positive cells showed the highest frequency of tumor formation in all times examined (Figure $1 \mathrm{H}-\mathrm{J}$ ). In addition, tumors originating from the ALDEFLUOR-positive cell implantations were much larger than tumors originating from the ALDEFLUOR-negative cells (Figure $1 \mathrm{~K}$ ). The tumor size and latency of tumor formation correlated well with the number of cells injected (Figure 1L). Remarkably, 50,000 and 5,000 ALDEFLUOR-positive cells generated tumors more efficiently than ALDEFLUOR-negative cells. In contrast, we did not see tumors at the 500 cell implantation dose with either ALDEFLUOR-positive or ALDEFLUORnegative cells. For further characterization, ALDEFLUORpositive and ALDEFLUOR-negative cells were plated in 96-well ultra-low attachment plates in serum-free medium containing $10 \mathrm{ng} / \mathrm{ml}$ EGF and $20 \mathrm{ng} / \mathrm{ml}$ bFGF to monitor mammospheres growth under a light microscope. Data obtained indicate that GI-101A ALDEFLUOR-positive cells showed two-fold higher mammosphere formation efficiency as did ALDEFLUOR-negative cells (Figure 1M).

\section{ALDEFLUOR-positive cells upon culture resemble the parental cell line $\mathrm{Gl}-101 \mathrm{~A}$}

The abilities of self-renewal and differentiation into heterogeneous cell types are the definition of stem cells, which are thought to be functionally mimicked by cancer stem cells [2,29-32]. To assess the capability of cancer stem-like cells to differentiate and reconstitute the composition of a were plated and allowed to expand in cell culture for 12 days. The growing cells were then analyzed for ALDH1 activity by flow cytometry (Figure 2). We found that cultures started with sorted ALDEFLUOR-positive cells resembled the parental cell line after being continuously passaged for three times. In terms of ALDH1 activity, it can be seen that the percentage of ALDEFLUOR-positive cells decreased from $82.8 \%$ to $18.9 \%$ after three passages in parental cell line, the sorted ALDEFLUOR-positive cells 


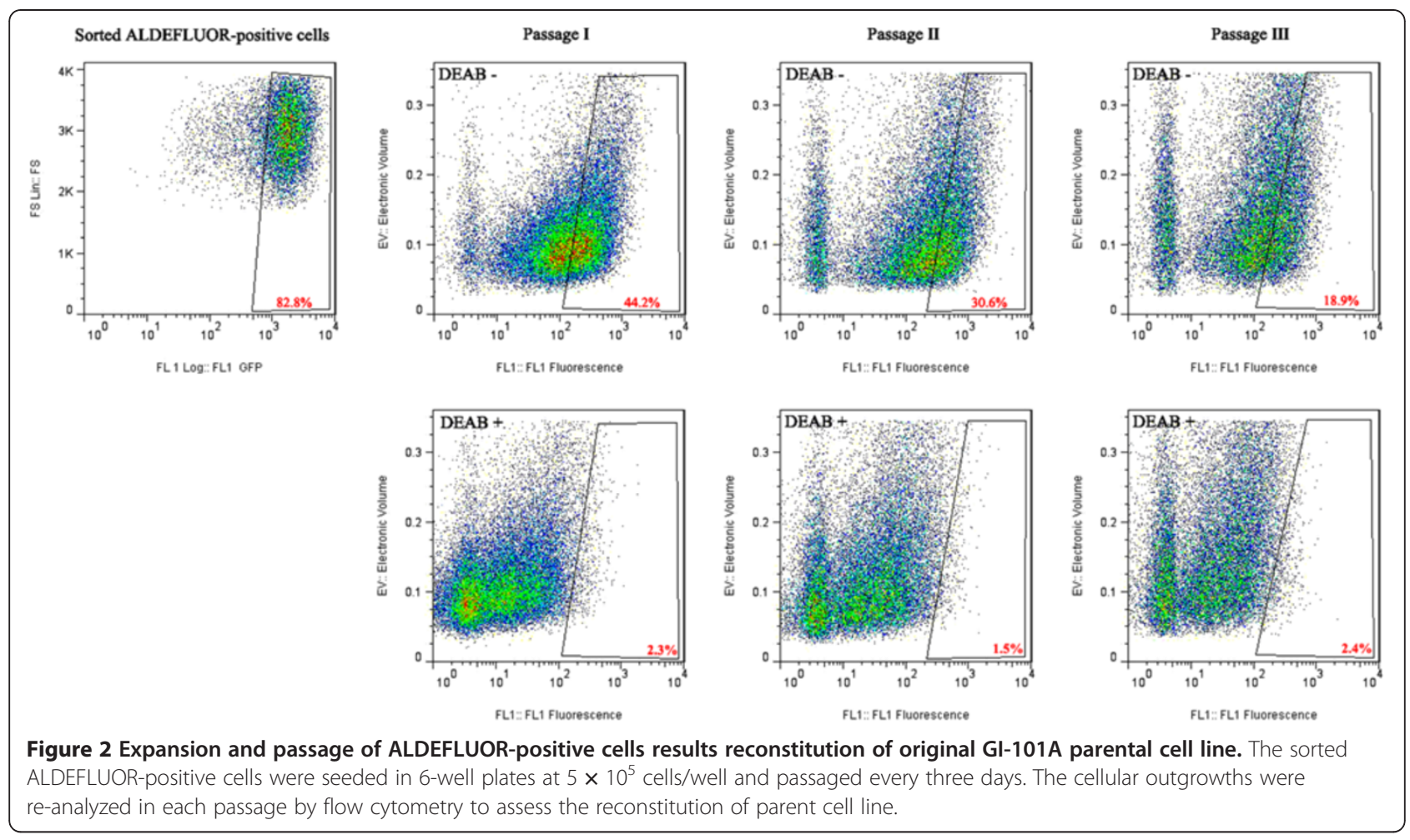

culture. These findings demonstrated that the cancer stem-like cells lose their stem cell marker in cell culture.

\section{ALDEFLUOR-positive cells exhibited enhanced resistance to chemo- and irradiation treatment when compared to ALDEFLUOR-negative cells}

It was reported that cancer stem cells in primary human leukemia and glioblastoma are resistant to chemotherapy $[33,34]$. To document that breast cancer cell line derived cancer stem-like cells are also resistant to chemotherapeutic agents. We treated ALDEFLUOR-positive and ALDEFLUOR-negative cells with increasing doses of breast cancer drugs such as 5 - FU $\left(10^{-7}, 10^{-6}, 10^{-5}, 10^{-4}\right.$, $\left.10^{-3} \mathrm{~mol} / \mathrm{L}\right)$, Carboplatin $\left(10^{-7}, 10^{-6}, 10^{-5}, 10^{-4}, \mathrm{~mol} / \mathrm{L}\right)$, Cisplatin $\left(10^{-7}, 10^{-6}, 10^{-5}, 10^{-4}, 10^{-3} \mathrm{~mol} / \mathrm{L}\right)$, Mitomycin-C $\left(10^{-8}, 10^{-7}, 10^{-6}, 10^{-5}, 10^{-4} \mathrm{~mol} / \mathrm{L}\right)$ and Salinomycin $\left(10^{-7}\right.$, $\left.10^{-6}, 10^{-5}, 10^{-4}, 10^{-3} \mathrm{~mol} / \mathrm{L}\right)$. ALDEFLUOR-positive cells exhibited a significantly higher survival rate in the presence of drugs than the ALDEFLUOR-negative cells (Figure 3A-E). Furthermore, we investigated the sensitivity of the two separated fractions of GI-101A breast cancer cells to irradiation. Cell survival assays were performed using increased doses from 0 Gy, 0.5 Gy, 1 Gy, 2 Gy and 4 Gy. We found that ALDEFLUOR-positive cells showed an increased survival after irradiation treatment in contrast to ALDEFLUOR-negative cell fraction, which exhibited less resistance to radiation treatment (Figure 3F).
ALDEFLUOR-positive cells showed higher expression levels of CD44, CD49f and CD24 surface marker proteins than ALDEFLUOR-negative cells

In breast tumors, a $\mathrm{CD} 44^{+} \mathrm{CD} 24^{-/{ }^{-l o w}} \mathrm{ESA}^{+}$lineage subpopulation was originally identified as the tumorigenic (tumor-initiating) fraction. This conclusion is based more on the ability of these cells to form tumors in NOD/SCID mice when injected at very low numbers [6]. Human breast cancer cell lines contain $\mathrm{CD} 44^{+} \mathrm{CD} 24^{-/{ }^{l o w}} \mathrm{ESA}^{+}$cells that exhibit characteristic stem cell features like anchorageindependent growth at clonal densities, the ability to reconstruct the parental cell fractions, along with enhanced tumorigenicity in mice $[9,31]$. The $\mathrm{CD} 44^{+} \mathrm{CD} 24^{- \text {low }}$ phenotype also correlates to the enhanced expression of pro-invasive genes such as IL- $1 \alpha$, IL-6, IL-8, urokinase plasminogen activator [UPA] and the ability to form distant metastases [35-37]. In addition, tumorigenicity of prospective breast CSCs has been linked to the expression of $\alpha 6$ integrin (CD49f) [38] and $\beta 1$ integrin [39]. To analyze the CD44/CD24/CD49f expression in ALDEFLUORpositive and ALDEFLUOR-negative cells, we performed an ALDEFLUOR assay followed by a CD44, CD24 and CD49f immunostaining of ALDEFLUOR-positive and ALDEFLUOR-negative cells (Figure 4). As shown in Figure 4A-B, the percentage of CD44+ in ALDEFLUORpositive cells reached to $97.89 \%$ (Figure 4A gate Q1 + Q2) or $94.99 \%$ (Figure 4B gate Q1 + Q2). However, the percentage of $\mathrm{CD}_{4} 4^{+}$in ALDEFLUOR-negative cells dropped to $85.23 \%$ or $81.83 \%$. Similarly, the percentage 


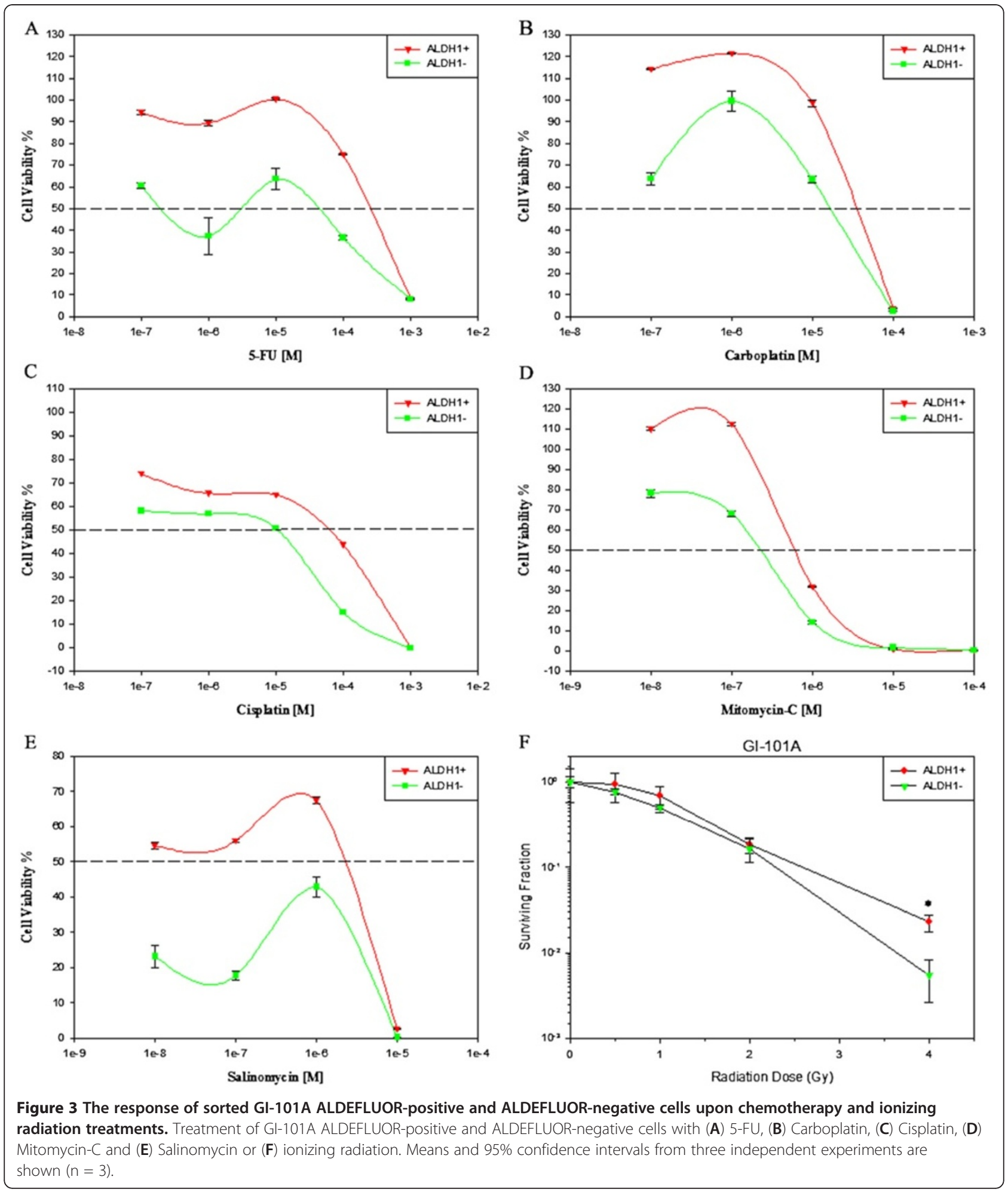

of CD49f ${ }^{+}$in ALDEFLUOR-positive cells reached 99.09\% (Figure 4B gate Q2 + Q3) and the percentage of CD49f $\mathrm{f}^{+}$ in ALDEFLUOR-negative cells dropped to $90.8 \%$. Furthermore, there was no significant difference in the CD24 expression between ALDEFLUOR-positive cells
(98.92\%, Figure 4A gate Q2 + Q3) and ALDEFLUORnegative cells $(96.3 \%)$. Considering those surface marker expression in combination, the percentage of $\mathrm{CD} 44^{+} \mathrm{CD} 24^{-}$in ALDEFLUOR-positive cells $(0.79 \%$, Figure 4A gate Q1) was much lower than that in 


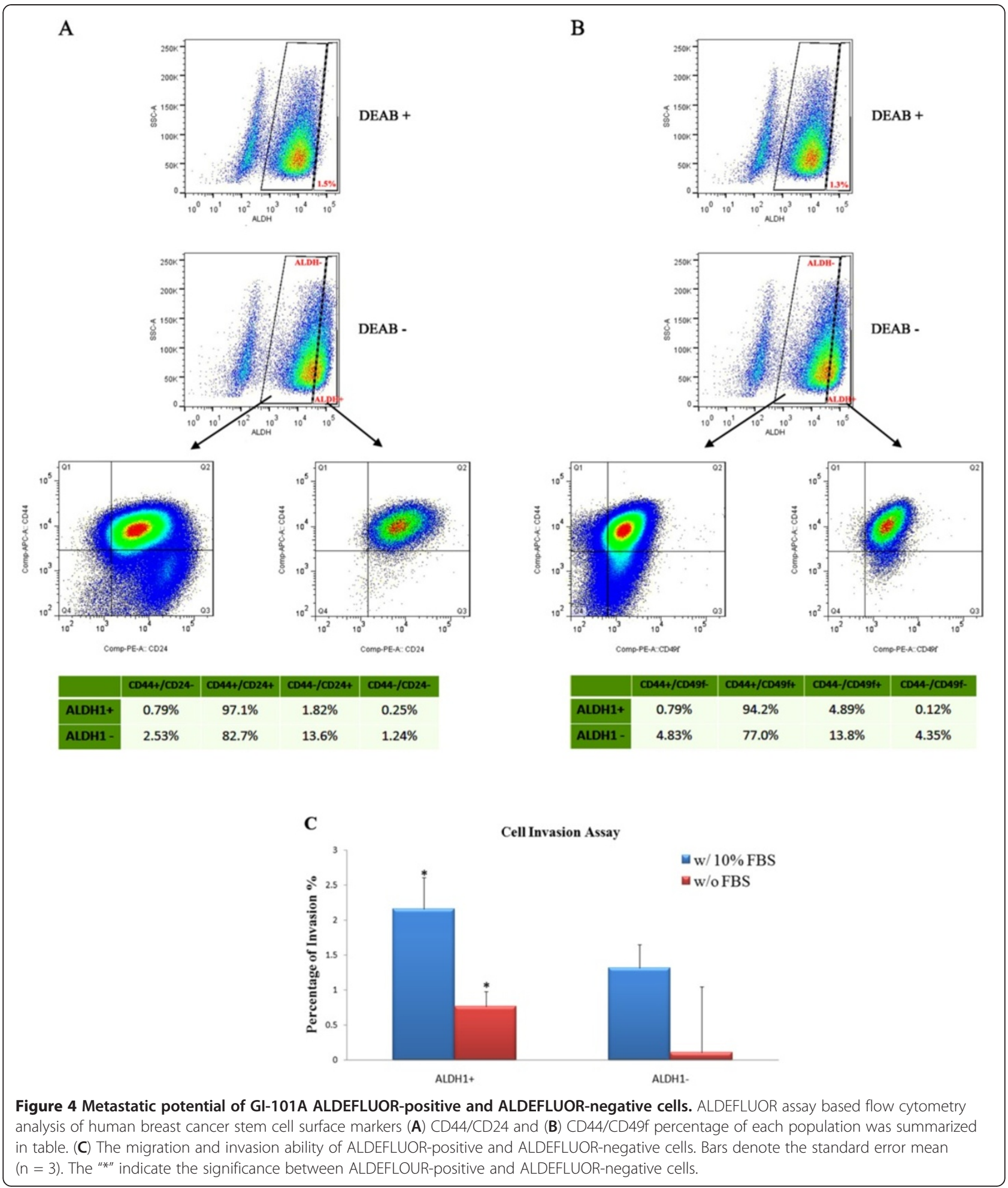

ALDEFLUOR-negative cells (2.53\%, Figure 4A gate Q1). And the percentage of $\mathrm{CD} 44^{+} \mathrm{CD} 49 \mathrm{f}^{+}$in ALDEFLUORpositive cells $(94.2 \%$, Figure $4 \mathrm{~B}$ gate Q2) was higher than that in ALDEFLUOR-negative cells (77.0\%, Figure 4B gate Q2). Considering both CD44 and CD49f could contribute to carcinoma progression and cancer metastases [40,41] and the ALDEFLUOR-positive breast cancer cells have also been reported to have cell invasion potential in vitro, which is related to metastases in vivo [42,43], we also performed Basement Membrane Extract (BME) invasion assay, using 
$10 \%$ fetal bovine serum as attractant, to examine the ability of ALDEFLUOR-positive and ALDEFLUOR-negative cells from GI-101A to invade in matrix gels. As shown in Figure $4 \mathrm{C}$, we found that ALDEFLUOR-positive cells demonstrated higher migration capability through BME than the ALDEFLUOR-negative cells. These results supported the notion that GI-101A ALDEFLUOR-positive cells exhibited invasive behavior.

\section{VACV GLV-1h68 strain replicates more efficiently in ALDEFLUOR-positive cells than in ALDEFLUOR-negative cells in culture}

We compared replication efficiency of the vaccinia virus strain GLV-1h68 in sorted ALDEFLUOR-positive and ALDEFLUOR-negative cells. Both cell cultures were infected with GLV-1h68 at an MOI of 0.01 or 10 , and the viral titer was determined at 1, 12, 24, 48 and 72 hours post infection. We found that at 72 hours post infection, the viral titer in ALDEFLUOR-positive cells was three times higher at MOI of 0.01 , and two times higher at MOI of 10 when compared to ALDEFLUOR-negative cells (Figure $5 \mathrm{~A}-\mathrm{B}$ ).

\section{VACV GLV-1h68 strain eradicates tumor xenografts derived from ALDEFLUOR-positive cells more efficiently than that derived from ALDEFLUOR-negative cells}

To test the efficacy of oncolytic vaccinia virus GLV-1h68 strain, tumors were established in the mammary fat pads of athymic nude mice by implantation of $5 \times 10^{3}$ sorted ALDEFLUOR-positive and ALDEFLUOR-negative GI101A cells. To facilitate the comparison of results, each mouse received two implantations, one into the left and another into the right mammary fat pads, respectively (e.g. $5 \times 10^{3}$ ALDEFLUOR-positive cells were placed into right fat pad and $5 \times 10^{3}$ ALDEFLUOR-negative cells into left fad pad or vice versa). Twelve weeks after tumor cell implantation, each mouse was administered with $5 \times 10^{6} \mathrm{pfu}$ of GLV-1h68 retro-orbitally. Both tumor size and virus mediated GFP expression in tumors were monitored weekly. Findings showed that the growth of both tumors was significantly inhibited by virus treatment. However, tumors derived from ALDEFLUOR-positive cells showed a more tumor size reduction after virus treatments, as opposed to tumors derived from ALDEFLUOR-negative implants (Figure 5D). After comparison of the fluorescence images from the tumors, we also found that tumors derived from ALDEFLUOR-positive cells originally had a more efficient GLV-1h68 replication and more fluorescence than tumors derived from ALDEFLUOR-negative cells (Figure 5C). More efficient virus replication resulted in faster tumor regression and earlier fluorescence detection.
EMT induction of $\mathrm{GI}-101 \mathrm{~A}$ cells resulted in cell population with $\mathrm{CD}_{4} 4^{+} \mathrm{CD} 24^{+} \mathrm{ESA}^{+}$and $\mathrm{CD} 44^{+} \mathrm{CD} 24^{-} \mathrm{ESA}^{+}$markers

We examined whether the treatment of GI-101A cell line with TGF- $\beta 1$, similar to HMLE cell line $[13,14]$, would lead to an enrichment of mesenchymal cells by losing E-cadherin and enhancing vimentin and fibronectin expression. We found that twelve days after TGF- $\beta 1$ treatment, EMT was observed in this cell line (Additional file 5: Figure S5). In comparison to GI-101A cells without TGF- $\beta 1$ treatment, the treated cells showed no difference in CD44 and ESA expression. However, the number of $\mathrm{CD}_{24}{ }^{+}$cells (P5: 7.59\%) increased after TGF- $\beta 1$ treatment, in contrast to cells without TGF- $\beta 1$ treatment (P5: 0.99\%) (Figure 6A). Therefore the treatment of GI-101A cells with TGF- $\beta 1$ did, in fact, induce a cell population with $\mathrm{CD} 44^{+} \mathrm{CD} 24^{+} \mathrm{ESA}^{+}$marker expression as opposed to $\mathrm{CD} 44^{+} \mathrm{CD} 24^{-} \mathrm{ESA}^{+}$. To examine whether $\mathrm{CD} 44^{+} \mathrm{CD} 24^{-} \mathrm{ESA}^{+}$or $\mathrm{CD} 44^{+} \mathrm{CD} 24^{+} \mathrm{ESA}^{+}$cells are cancer stem-like cells and to further investigated their tumorigenic potential, we implanted 10,000, 1,000, and 100 cells into the mammary fat pads of nude mice. Tumors were detected in the mice injected with $10,000 \mathrm{CD} 44^{+} \mathrm{CD} 24^{+} \mathrm{ESA}^{+}$ cells seven weeks after implantation. By 22 weeks after implantation, the tumor size had reached $700 \mathrm{~mm}^{3}$ in volume in contrast to $200 \mathrm{~mm}^{3}$ of tumors derived from $\mathrm{CD} 4^{+} \mathrm{CD} 24^{-} \mathrm{ESA}^{+}$cells (Figure $6 \mathrm{~B}$ ). Taken together, the $\mathrm{CD}_{4} 4^{+} \mathrm{CD} 24^{+} \mathrm{ESA}^{+}$cell population is 3.5 fold more tumorigenic than the CD44 ${ }^{+} \mathrm{CD} 24^{-} \mathrm{ESA}^{+}$cell population.

VACV GLV-1h68 strain shows higher replication in GI$101 \mathrm{~A}$ derived $\mathrm{CD} 44^{+} \mathrm{CD} 24^{+} \mathrm{ESA}^{+}$cells resulting in increased eradication of $\mathrm{CD} 44^{+} \mathrm{CD} 24^{+} \mathrm{ESA}^{+}$cells derived tumor xenografts.

We tested the ability of two VACVs to replicate in TGF- $\beta 1$ treated and untreated cells. Twelve days after TGF- $\beta 1$ treatment of cell lines, HMLE and GI-101A were infected with either GLV-1h68 strain, which carries a GFP fluorescent protein expression cassette, or GLV1h190 strain, similar to GLV-1h68, but expressing TurboFP635 fluorescent protein. We found a preferential VACV replication resulting in enhanced light emission in the area of EMT cells (Additional file 6: Figure S6). To document higher replication efficiency of GLV-1h68 strain in sorted $\mathrm{CD} 44^{+} \mathrm{CD} 24^{+} \mathrm{ESA}^{+}$in comparison to $\mathrm{CD}_{4} 4^{+} \mathrm{CD} 24^{-} \mathrm{ESA}^{+}$cells, we performed a virus infection followed by a replication assay. Both groups of cells were infected with GLV-1h68 at an MOI of 0.01 or 10 , and the viral titers were determined at 1, 12, 24, 48 and 72 hours post infection. At 72 hours post infection, the virus titer in $\mathrm{CD}_{4} 4^{+} \mathrm{CD} 24^{+} \mathrm{ESA}^{+}$cells was approximately fifteen times higher at MOI 0.01, and ten times higher at MOI 10 in comparison to $\mathrm{CD} 44^{+} \mathrm{CD} 24^{-} \mathrm{ESA}^{+}$cells (Figures 7A$\mathrm{B})$. To test whether the higher replication efficiency would result in enhanced oncolytic virus efficacy, we established tumors in the mammary fat pads of athymic nude mice by injection of 10,000 of sorted $\mathrm{CD} 44^{+} \mathrm{CD} 24^{+} \mathrm{ESA}^{+}$and 


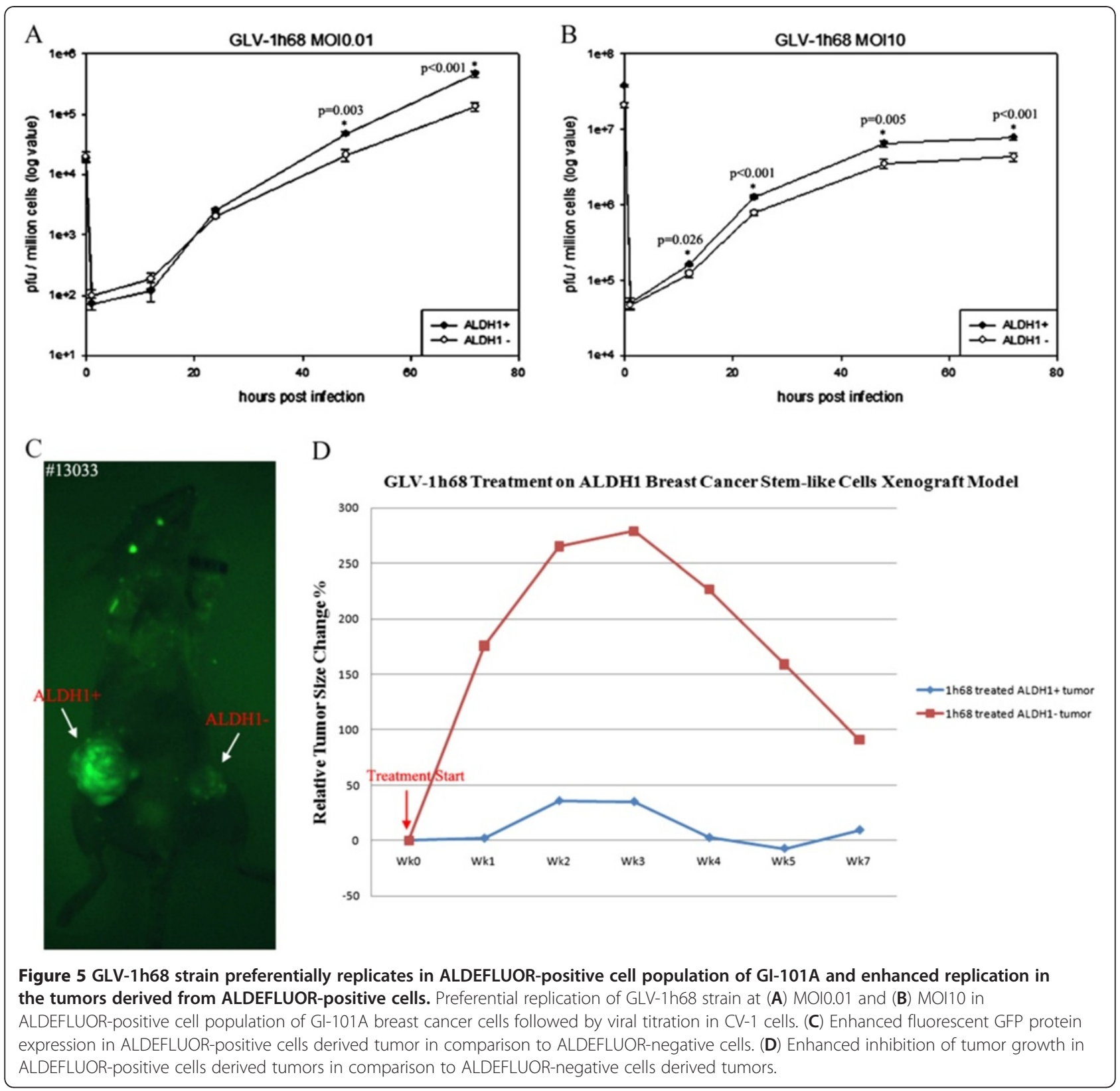

CD $44^{+} \mathrm{CD} 24^{-} \mathrm{ESA}^{+} \mathrm{GI}-101 \mathrm{~A}$ cells. In contrast to tumorigenicity experiments described before, each mouse was implanted with both cell fractions in these experiments, one fraction $\left(\mathrm{CD} 44^{+} \mathrm{CD} 24^{+} \mathrm{ESA}^{+}\right)$in right mammary fat pads and the other fraction $\left(\mathrm{CD} 44^{+} \mathrm{CD} 24^{-} \mathrm{ESA}^{+}\right)$in left, with 10,000 sorted cells. Twenty-two weeks after cell implantation, each mouse received $5 \times 10^{6}$ pfu of GLV-1h68 strain via the retro-orbital path. We monitored the tumor size as well as tumor GFP expression weekly by fluorescent imaging (Figure 7C). We found that tumor growth was generally inhibited after virus treatment in both left and right breast tumors. However, tumors derived from $\mathrm{CD}_{4} 4^{+} \mathrm{CD} 24^{+} \mathrm{ESA}^{+}$cells showed a greater size reduction than tumors derived from $\mathrm{CD} 44^{+} \mathrm{CD} 24^{-} \mathrm{ESA}^{+}$cells (Figure 7D). In summary, CD $44^{+} \mathrm{CD} 24^{+} \mathrm{ESA}^{+}$cells did support a more efficient virus replication and the higher virus titer caused more rapid tumor elimination in nude mice with $\mathrm{CD} 44^{+} \mathrm{CD} 24^{+} \mathrm{ESA}^{+}$cells derived tumor xenografts.

\section{Discussion}

The CSC hypothesis has fundamental implications in cancer biology, in clinical cancer risk assessment, and in the early detection, prognosis, and prevention of cancer. The development of cancer therapeutics based on tumor regression may have produced agents which kill 


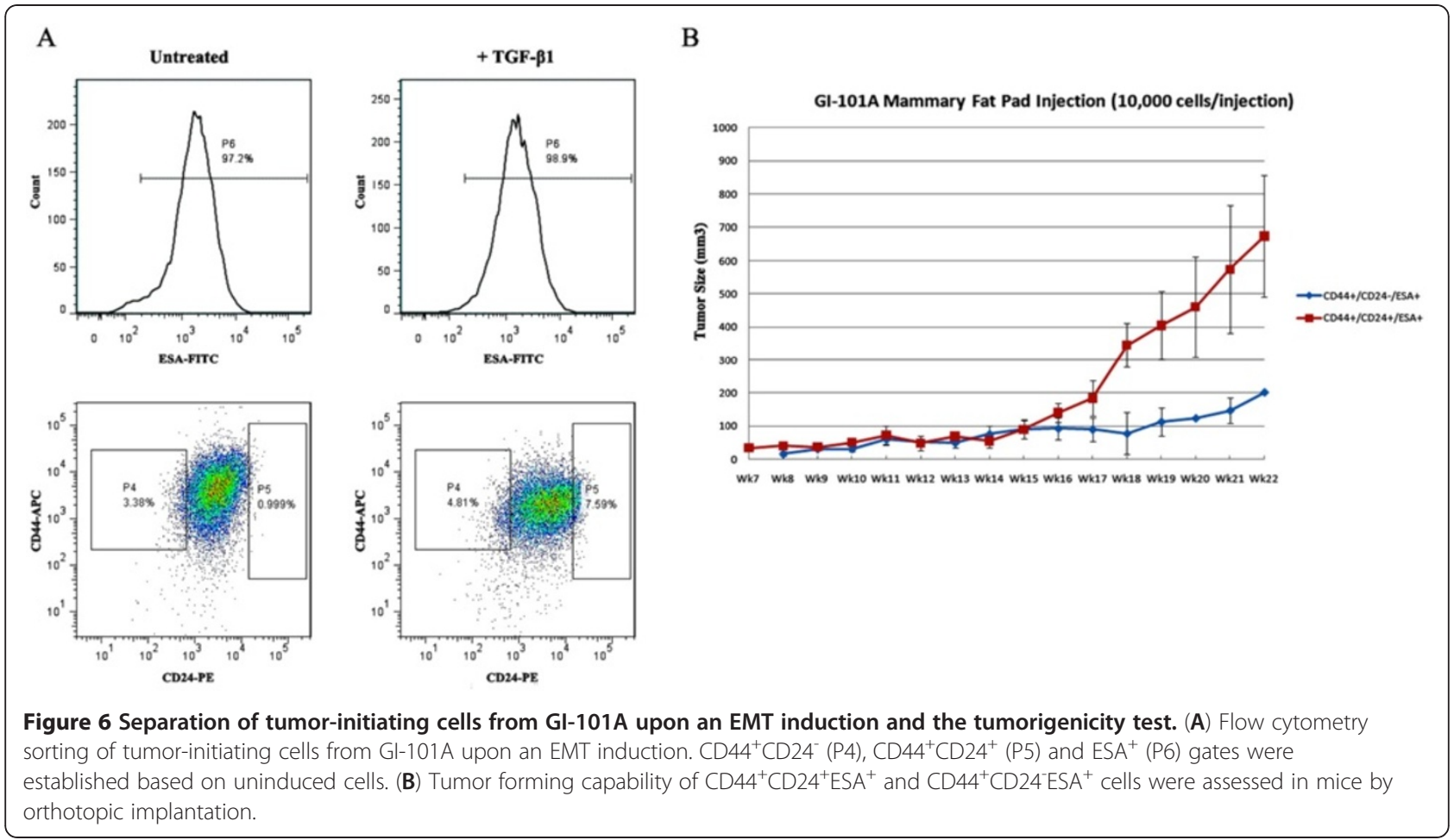

differentiated tumor cells, while a small CSC population become resistant and escape from drug therapy [5]. Cancer stem cell identification was largely based on primary cells as well as early passage of cell lines in a mouse xenograft model $[6,44]$. However, the success of establishing breast tumor xenografts for cancer stem cell identification has been low mainly due to lack of breast cancer stem cell markers. Cultured and passaged cell lines are readily available to provide more uniform cell populations in mouse xenograft models without the influence of human healthy tissues and human stroma $[45,46]$. These differentiated cancer cells have a very small number $(0.1-1 \%)$ of undifferenated cells with cancer stem cell markers [12]. The quantity of cancer stem cells derived from patient samples is limited. Therefore, the establishment of relevant cancer stem-like cell models in cell culture and in mouse tumor xenograft models is critical for the study of cancer stemlike cell characterization and therapy.

According to recently described findings [7], the cell sorter based fluorescent ALDEFLUOR assay, in combination with ALDH1 immunostaining may prove to be critical for the detection and isolation of CSCs from epithelial tumor samples, thus facilitating CSC isolation/identification in the clinical practice and on the cell culture level. In this study, we have successfully identified, isolated and characterized ALDEFLUOR-positive cells from GI-101A breast cancer cell line with cancer stem-like characteristics. We found that less than $5 \times 10^{3}$ ALDEFLUOR-positive cells did generate tumors six weeks after implantation in nude mice and did grow to a size of $2,000 \mathrm{~mm}^{3}$ at nineteen weeks. Cells with low levels of ALDH1 (ALDEFLUORnegative) initiated tumor growth at six weeks after implantation in one mouse and did grow remarkably slower, reaching a size of $200 \mathrm{~mm}^{3}$ at nineteen weeks. Judging by tumor formation frequency and tumor growth, ALDEFLUORpositive cell exhibit more cancer stem-like cell growth morphology than ALDEFLUOR-negative cells. These findings were also confirmed by mammosphere formation assay in cell culture. Furthermore, the ALDEFLUOR-positive cells displayed enhanced resistance to five chemotherapy drugs as well as to irradiation in cell cultures. Self-renewal or asymmetrical division is also a unique feature associated with stem cells/cancer stem cells. When the sorted ALDEFLUOR-positive cells were cultured continually on plates, the fraction of ALDEFLUOR-negative cells increased from $17 \%$ to $80 \%$ approximately. Finally, the ratio between ALDEFLUOR-positive and -negative cells reached to a level, similar to that of GI-101A cell culture before sorting. To further characterize ALDEFLUOR-positive cells, we combined the ALDEFLUOR assay with known breast cancer stem cell surface marker analysis. Interestingly, we found that the ALDEFLUOR-positive cell population exhibited elevated CD44 and CD49f expression compared to the ALDEFLUOR-negative cell population. These findings are consistent with previously published data that both CD44 and $\mathrm{CD} 49 \mathrm{f}$ marker proteins contribute to carcinoma 


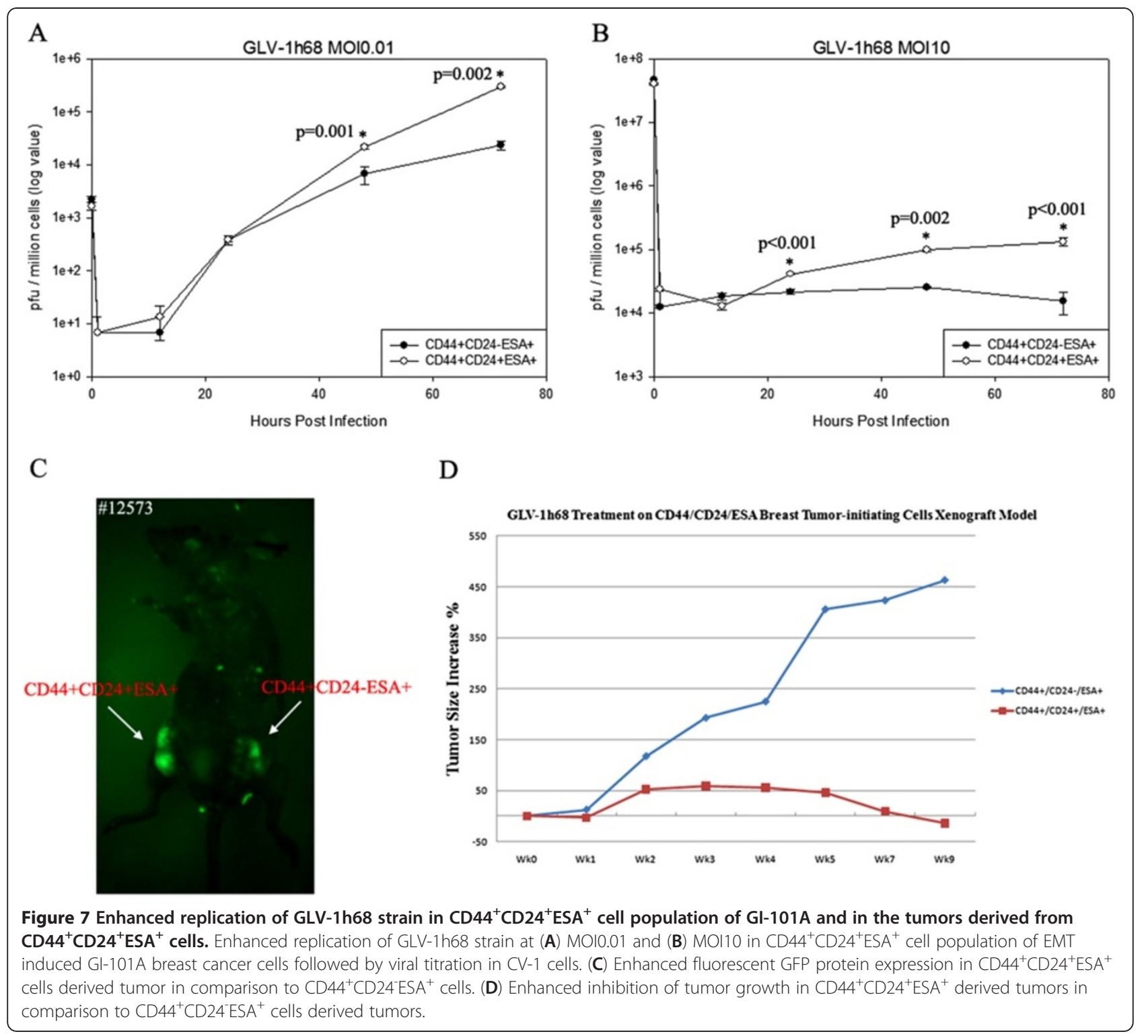

progression and cancer metastases [38]. Cancer stem cells may also be responsible for mediating tumor metastases process. A link between cancer stem cells and secondary tumor metastases was first suggested after the identification of "stemness" and an 11-gene signature therapy resistant profile of metastatic and primary tumors in prostate cancer of a transgenic mouse model, as well as in cancer patients [47]. This signature was also a powerful predictor of disease recurrence, survival after therapy, and distant metastases in a variety of cancer types. Here we also demonstrated that ALDEFLUOR-positive cells migrated more efficiently than ALDEFLUOR-negative cells in BME transwells, indicating the increased metastatic potential of GI-101A ALDEFLUOR-positive cells. Contrary to current 'CD $44^{+} \mathrm{CD} 24^{-/ \text {low }}$ centric' thought regarding the developmental plasticity of tumor-initiating mammary epithelial cells $[6,48]$, recent studies have revealed that not only $\mathrm{CD} 44^{+} \mathrm{CD} 24^{- \text {low }}$ cells can give rise to $\mathrm{CD} 44^{+} \mathrm{CD} 24^{+}$ cells, as expected for a cancer stem cell [49], but that the converse can also occur; $\mathrm{CD} 44^{+} \mathrm{CD} 24^{+}$cells can give rise to their $\mathrm{CD} 44^{+} \mathrm{CD} 24^{-/ \text {low }}$ counterparts and single cells from either phenotype are capable of initiating tumors as xenografts with high efficiency [50]. Surprisingly, we also found that ALDEFLUOR-positive cells had enhanced CD24 expression levels. These findings do contradict with known and accepted human breast cancer stem cell markers, which are elevated CD44 and reduced CD24. To confirm that the expression of CD24 is also associated with tumorigenicity, we established a CD $44^{+} \mathrm{CD} 24^{+} \mathrm{ESA}^{+}$and a CD $44^{+} \mathrm{CD} 24^{-} \mathrm{ESA}^{+}$fraction from GI-101A cell line after 
EMT induction. In these experiments we showed that $\mathrm{CD} 24^{+}$cells initiated tumors more efficiently than the CD24- cells. This explains why ALDEFLUOR-negative cells are less tumorigenic than ALDEFLUOR-positive cells. Since ALDEFLUOR-positive cells showed also higher expression of CD24, similarly to EMT cell population, and both exhibited enhanced tumorigenicity, we suggest that the elevated CD24 expression is a reliable CSC marker in this cell line and that GI-101A cancer stem-like cell markers are ALDH1 ${ }^{+} \mathrm{CD} 44^{+} \mathrm{CD} 24^{+} \mathrm{ESA}^{+}$. Taken together, our results indicated the phenotype of cancer stem cells is complex and the markers of cancer stem cells vary among different cell sources.

We have reported earlier that after a single intravenous injection of VACV GLV-1h68 strain, more than two dozen human tumors and metastases in nude mice were efficiently colonized and eradicated $[51,52]$. The importance of cancer stem cells in tumor initiation and their resistance to current therapies require the development of novel therapies for both tumor elimination and prevention of tumor recurrence. The data presented in this manuscript clearly indicate that the VACV GLV-1h68 strain infects the $\mathrm{ALDH}_{1}{ }^{+} \mathrm{CD} 44^{+} \mathrm{CD} 24^{+} \mathrm{ESA}^{+}$cell population more efficiently than the $\mathrm{ALDH} 1^{-} \mathrm{CD} 44^{+} \mathrm{CD} 24{ }^{-} \mathrm{ESA}^{+}$cell population. The more efficient infection resulted in enhanced cytotoxicity and cell lysis in cell culture. Furthermore, this virus also replicated more efficiently in tumors generated from cancer stem-like cells. Lastly, the enhanced viral replication in the tumor xenograft derived from cancer stemlike $\mathrm{ALDH} 1{ }^{+} \mathrm{CD} 44^{+} \mathrm{CD} 24^{+} \mathrm{ESA}^{+}$cell implantation led to a more efficient elimination of tumors, in comparison to ALDH1 ${ }^{-} \mathrm{CD} 44^{+} \mathrm{CD} 24{ }^{-} \mathrm{ESA}^{+}$cell derived xenografts. Based on these experiments, either chemotherapy drug resistant or irradiation resistant cancer stem-like cells were identified in cell culture and no further recurrence was seen in treated mice carrying tumors derived from both ALDEFLUOR-positive cell population and $\mathrm{CD}_{2} 4^{+}$cell population.

\section{Conclusion}

In conclusion, the combination of ALDEFLUOR assay and identification of cancer stem-like cells upon TGF- $\beta 1$ induced EMT may allow the isolation of cancer stem-like cells from tumor cell lines and tumor biopsies. Further, the cancer stem-like cells showed elevated replication and cytotoxicity of two VACV strains, GLV-1h68 and GLV1h190. Mice carrying cancer stem-like cell tumor xenografts were efficiently colonized and their tumors were more rapidly eradicated than tumors grown from ALDEFLUOR-negative and CD24- tumor cell population. Therefore, VACV based oncolytic viral therapy may result in efficient eradication of solid tumors, secondary metastases including cancer stem-like cells in tumors as well as circulating tumor cells in blood.

\section{Additional files}

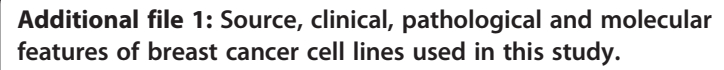

Additional file 2: Morphology of human breast cancer cell lines in cell culture. (A) Gl-101A; (B) MCF-7; (C) MDA-MB-231; (D) Hs 578 T; (E) SUM149PT.

Additional file 3: Flow cytometry analysis of ALDH activity in human breast cancer cell lines.

Additional file 4: Detection of ALDEFLUOR-positive cells from GI-101A stained by ALDEFLUOR dye in vitro with DEAB $(C, D)$ or without $\operatorname{DEAB}(A, B)$.

Additional file 5: EMT in HMLE and GI-101A cancer cells: Epithelial marker E-cadherin down-regulated and mesenchymal marker Vimentin and Fibronectin up-regulated.

Additional file 6: Enhanced VACV replication in TGF- $\beta 1$ treated cells. (A) HMLE and (B) Gl-101A cells were treated for 12 days followed by infection of GLV-1h68 strain and GLV-1h190 strain at MOl10. The images were taken at 6, 8, 10 and $12 \mathrm{hpi}$ and the red arrows indicate the onset of GFP expression.

\section{Abbreviations}

CSCs: Cancer stem cells; VACV: Vaccinia virus; ALDH1: Aldehyde dehydrogenase 1; EMT: Epithelial-Mesenchymal Transition; NOD/ SCID: Nonobese/severe combined immunodeficient; ATCC: American Type Culture Collection; HMLE: Immortalized human mammary epithelial cells; EGF: Epidermal growth factor; TGF: Transforming growth factor; BME: Basement Membrane Extract; DEAB: Diethylaminobenzaldehyde.

\section{Competing interests}

H. Wang, N. G. Chen, B. R. Minev and A. A. Szalay are salaried employees of Genelux Corporation.

\section{Authors' contributions}

HW helped with study design, performing and writing of the manuscript. NGC, BRM and AAS conceived the study and study design and guided the writing and editing of the manuscript. All authors read and approved the final manuscript.

\section{Acknowledgements}

The authors thank J. Aguilar, T. Trevino and M. Fells for excellent technical assistance. We thank Professor Robert A. Weinberg for kindly providing us with HMLE cells, the EMT model cell line. This work was supported by a research grant from Genelux Corporation (R\&D facility in San Diego, CA, USA). We also thank J. Aguilar and J. Kramer for proofreading of the manuscript. H. Wang was a visiting graduate student from Prof. Szalay's laboratory in the Institute of Biochemistry, University of Würzburg, Germany, supported by a graduate stipend and foreign travel grant from Genelux corporation.

\section{Author details}

${ }^{1}$ Institute of Biochemistry, Biocenter, University of Würzburg, Am hubland, D-97074, Würzburg, Germany. ${ }^{2}$ Genelux Corporation, San Diego Science Center, 3030 Bunker Hill Street, Suite 310, San Diego, CA 92109, USA.

${ }^{3}$ Department of Radiation Oncology, Rebecca \& John Moores Comprehensive Cancer Center, University of California, San Diego, La Jolla, CA 92093, USA. ${ }^{4}$ UCSD Division of Neurosurgery, University of California, San Diego, La Jolla, CA 92093, USA. ${ }^{5}$ Rudolf Virchow Center for Experimental Biomedicine and Institute for Molecular Infection Biology, University of Würzburg, Am hubland, D-97074, Würzburg, Germany.

Received: 7 April 2012 Accepted: 2 August 2012

Published: 17 August 2012

\section{References}

1. Al-Hajj M, Becker MW, Wicha M, Weissman I, Clarke MF: Therapeutic implications of cancer stem cells. Curr Opin Genet Dev 2004, 14:43-47. 
2. Bonnet D, Dick JE: Human acute myeloid leukemia is organized as a hierarchy that originates from a primitive hematopoietic cell. Nat Med 1997, 3:730-737.

3. Li F, Tiede B, Massague J, Kang Y: Beyond tumorigenesis: cancer stem cells in metastasis. Cell Res 2007, 17:3-14.

4. Phillips TM, McBride WH, Pajonk F: The response of CD24(-/low)/CD44+ breast cancer-initiating cells to radiation. J Natl Cancer Inst 2006, 98:1777-1785.

5. Wicha MS, Liu S, Dontu G: Cancer stem cells: an old idea--a paradigm shift. Cancer Res 2006, 66:1883-1890. discussion 1895-1886.

6. Al-Hajj M, Wicha MS, Benito-Hernandez A, Morrison SJ, Clarke MF: Prospective identification of tumorigenic breast cancer cells. Proc Nat/ Acad Sci U S A 2003, 100:3983-3988.

7. Ginestier $\mathrm{C}$, Hur MH, Charafe-Jauffret E, Monville F, Dutcher J, Brown M, Jacquemier J, Viens P, Kleer CG, Liu S, et al: ALDH1 is a marker of normal and malignant human mammary stem cells and a predictor of poor clinical outcome. Cell Stem Cell 2007, 1:555-567.

8. Christgen M, Ballmaier M, Bruchhardt $H$, von Wasielewski R, Kreipe $H$, Lehmann U: Identification of a distinct side population of cancer cells in the Cal-51 human breast carcinoma cell line. Mol Cell Biochem 2007, 306:201-212.

9. Fillmore CM, Kuperwasser C: Human breast cancer cell lines contain stemlike cells that self-renew, give rise to phenotypically diverse progeny and survive chemotherapy. Breast Cancer Res 2008, 10:R25.

10. Kondo T, Setoguchi T, Taga T: Persistence of a small subpopulation of cancer stem-like cells in the C6 glioma cell line. Proc Natl Acad Sci U S A 2004, 101:781-786.

11. Setoguchi $T$, Taga $T$, Kondo $T$ : Cancer stem cells persist in many cancer cell lines. Cell Cycle 2004, 3:414-415.

12. Charafe-Jauffret E, Ginestier C, lovino F, Wicinski J, Cervera N, Finetti P, Hur $\mathrm{MH}$, Diebel ME, Monville F, Dutcher J, et al: Breast cancer cell lines contain functional cancer stem cells with metastatic capacity and a distinct molecular signature. Cancer Res 2009, 69:1302-1313.

13. Mani SA, Guo W, Liao MJ, Eaton EN, Ayyanan A, Zhou AY, Brooks M, Reinhard F, Zhang CC, Shipitsin M, et al: The epithelial-mesenchymal transition generates cells with properties of stem cells. Cell 2008, 133:704-715.

14. Morel AP, Lievre M, Thomas C, Hinkal G, Ansieau S, Puisieux A: Generation of breast cancer stem cells through epithelial-mesenchymal transition. PLoS One 2008, 3:e2888.

15. Gupta PB, Onder TT, Jiang G, Tao K, Kuperwasser C, Weinberg RA, Lander ES: Identification of selective inhibitors of cancer stem cells by highthroughput screening. Cell 2009, 138:645-659.

16. Chen N, Szalay AA: Oncolytic vaccinia virus: a theranostic agent for cancer. Futur Virol 2010, 5:763-784.

17. Weibel S, Raab V, Yu YA, Worschech A, Wang E, Marincola FM, Szalay AA: Viral-mediated oncolysis is the most critical factor in the late-phase of the tumor regression process upon vaccinia virus infection. BMC Cancer 2011, 11:68.

18. Hofmann E, Grummt F, Szalay AA: Vaccinia virus GLV-1 h237 carrying a Walker A motif mutation of mouse Cdc6 protein enhances human breast tumor therapy in mouse xenografts. Int J Oncol 2011, 38:871-878.

19. Zhang Q, Liang C, Yu YA, Chen N, Dandekar T, Szalay AA: The highly attenuated oncolytic recombinant vaccinia virus GLV-1h68: comparative genomic features and the contribution of F14.5L inactivation. Mol Genet Genomics 2009, 282:417-435.

20. Yu YA, Zhang Q, Szalay AA: Establishment and characterization of conditions required for tumor colonization by intravenously delivered bacteria. Biotechnol Bioeng 2008, 100:567-578.

21. Zhang Q, Yu YA, Wang E, Chen N, Danner RL, Munson PJ, Marincola FM, Szalay AA: Eradication of solid human breast tumors in nude mice with an intravenously injected light-emitting oncolytic vaccinia virus. Cancer Res 2007, 67:10038-10046.

22. Chen N, Zhang Q, Yu YA, Stritzker J, Brader P, Schirbel A, Samnick S, Serganova I, Blasberg R, Fong Y, Szalay AA: A novel recombinant vaccinia virus expressing the human norepinephrine transporter retains oncolytic potential and facilitates deep-tissue imaging. Mol Med 2009, 15:144-151.

23. Worschech A, Chen N, Yu YA, Zhang Q, Pos Z, Weibel S, Raab V, Sabatino M Monaco A, Liu H, et al: Systemic treatment of xenografts with vaccinia virus GLV-1h68 reveals the immunologic facet of oncolytic therapy. BMC Genomics 2009, 10:301.
24. Seubert CM, Stritzker J, Hess M, Donat U, Sturm JB, Chen N, von Hof JM, Krewer B, Tietze LF, Gentschev I, Szalay AA: Enhanced tumor therapy using vaccinia virus strain GLV-1h68 in combination with a beta-galactosidaseactivatable prodrug seco-analog of duocarmycin SA. Cancer Gene Ther 2010, 18:42-52.

25. Rathinavelu P, Malave A, Raney SR, Hurst J, Roberson CT, Rathinavelu A: Expression of mdm-2 oncoprotein in the primary and metastatic sites of mammary tumor (Gl-101) implanted athymic nude mice. Cancer Biochem Biophys 1999, 17:133-146.

26. Morrissey JJ, Raney S: A metastatic breast tumor cell line, GI-101A, is estrogen receptor positive and responsive to estrogen but resistant to tamoxifen. Cell Biol Int 1998, 22:413-419.

27. Hurst J, Maniar N, Tombarkiewicz J, Lucas F, Roberson C, Steplewski Z, James W, Perras J: A novel model of a metastatic human breast tumour xenograft line. Br J Cancer 1993, 68:274-276.

28. Dontu G, Abdallah WM, Foley JM, Jackson KW, Clarke MF, Kawamura MJ, Wicha MS: In vitro propagation and transcriptional profiling of human mammary stem/progenitor cells. Genes Dev 2003, 17:1253-1270.

29. Pardal R, Clarke MF, Morrison SJ: Applying the principles of stem-cell biology to cancer. Nat Rev Cancer 2003, 3:895-902.

30. Singh SK, Clarke ID, Terasaki M, Bonn VE, Hawkins C, Squire J, Dirks PB: Identification of a cancer stem cell in human brain tumors. Cancer Res 2003, 63:5821-5828

31. Ponti D, Costa A, Zaffaroni N, Pratesi G, Petrangolini G, Coradini D, Pilotti S, Pierotti MA, Daidone MG: Isolation and in vitro propagation of tumorigenic breast cancer cells with stem/progenitor cell properties. Cancer Res 2005, 65:5506-5511.

32. Li C, Heidt DG, Dalerba P, Burant CF, Zhang L, Adsay V, Wicha M, Clarke MF, Simeone DM: Identification of pancreatic cancer stem cells. Cancer Res 2007, 67:1030-1037.

33. Costello RT, Mallet F, Gaugler B, Sainty D, Arnoulet C, Gastaut JA, Olive D: Human acute myeloid leukemia CD34+/CD38- progenitor cells have decreased sensitivity to chemotherapy and Fas-induced apoptosis, reduced immunogenicity, and impaired dendritic cell transformation capacities. Cancer Res 2000, 60:4403-4411.

34. Liu G, Yuan X, Zeng Z, Tunici P, Ng H, Abdulkadir IR, Lu L, Irvin D, Black KL, Yu JS: Analysis of gene expression and chemoresistance of CD133+ cancer stem cells in glioblastoma. Mol Cancer 2006, 5:67.

35. Abraham BK, Fritz P, McClellan M, Hauptvogel P, Athelogou M, Brauch H: Prevalence of CD44+/CD24-/low cells in breast cancer may not be associated with clinical outcome but may favor distant metastasis. Clin Cancer Res 2005, 11:1154-1159.

36. Balic M, Lin H, Young L, Hawes D, Giuliano A, McNamara G, Datar RH, Cote RJ: Most early disseminated cancer cells detected in bone marrow of breast cancer patients have a putative breast cancer stem cell phenotype. Clin Cancer Res 2006, 12:5615-5621.

37. Sheridan C, Kishimoto $H$, Fuchs RK, Mehrotra S, Bhat-Nakshatri $P$, Turner $\mathrm{CH}_{\text {, }}$ Goulet R Jr, Badve S, Nakshatri H: CD44+/CD24- breast cancer cells exhibit enhanced invasive properties: an early step necessary for metastasis. Breast Cancer Res 2006, 8:R59.

38. Cariati M, Naderi A, Brown JP, Smalley MJ, Pinder SE, Caldas C, Purushotham AD: Alpha-6 integrin is necessary for the tumourigenicity of a stem cell-like subpopulation within the MCF7 breast cancer cell line. Int $J$ Cancer 2008, 122:298-304.

39. Crowe DL, Ohannessian A: Recruitment of focal adhesion kinase and paxillin to beta1 integrin promotes cancer cell migration via mitogen activated protein kinase activation. BMC Cancer 2004, 4:18

40. Lipscomb EA, Mercurio AM: Mobilization and activation of a signaling competent alpha6beta4integrin underlies its contribution to carcinoma progression. Cancer Metastasis Rev 2005, 24:413-423.

41. Liu H, Patel MR, Prescher JA, Patsialou A, Qian D, Lin J, Wen S, Chang YF, Bachmann $\mathrm{MH}$, Shimono $\mathrm{Y}$, et al: Cancer stem cells from human breast tumors are involved in spontaneous metastases in orthotopic mouse models. Proc Natl Acad Sci U S A 2010, 107:18115-18120.

42. Charafe-Jauffret E, Ginestier C, lovino F, Tarpin C, Diebel M, Esterni B, Houvenaeghel G, Extra JM, Bertucci F, Jacquemier J, et al: Aldehyde dehydrogenase 1-positive cancer stem cells mediate metastasis and poor clinical outcome in inflammatory breast cancer. Clin Cancer Res 2009, 16:45-55.

43. Croker AK, Goodale D, Chu J, Postenka C, Hedley BD, Hess DA, Allan AL: High aldehyde dehydrogenase and expression of cancer stem cell 
markers selects for breast cancer cells with enhanced malignant and metastatic ability. J Cell Mol Med 2009, 13:2236-2252.

44. Ricci-Vitiani L, Lombardi DG, Pilozzi E, Biffoni M, Todaro M, Peschle C, De Maria R: Identification and expansion of human colon-cancer-initiating cells. Nature 2007, 445:111-115.

45. Neve RM, Chin K, Fridlyand J, Yeh J, Baehner FL, Fevr T, Clark L, Bayani N, Coppe JP, Tong F, et al: A collection of breast cancer cell lines for the study of functionally distinct cancer subtypes. Cancer Cell 2006, 10:515-527.

46. Charafe-Jauffret $E$, Ginestier $C$, Monville F, Finetti P, Adelaide J, Cervera N, Fekairi S, Xerri L, Jacquemier J, Birnbaum D, Bertucci F: Gene expression profiling of breast cell lines identifies potential new basal markers. Oncogene 2006, 25:2273-2284.

47. Glinsky GV, Berezovska O, Glinskii AB: Microarray analysis identifies a death-from-cancer signature predicting therapy failure in patients with multiple types of cancer. J Clin Invest 2005, 115:1503-1521.

48. Nakshatri $\mathrm{H}$, Srour EF, Badve $\mathrm{S}$ : Breast cancer stem cells and intrinsic subtypes: controversies rage on. Curr Stem Cell Res Ther 2009, 4:50-60.

49. Shipitsin M, Polyak K: The cancer stem cell hypothesis: in search of definitions, markers, and relevance. Lab Invest 2008, 88:459-463.

50. Meyer MJ, Fleming JM, Ali MA, Pesesky MW, Ginsburg E, Vonderhaar BK: Dynamic regulation of $C D 24$ and the invasive, $C D 44$ pos CD24neg phenotype in breast cancer cell lines. Breast Cancer Res 2009, 11:R82.

51. Kelly K, Brader P, Woo Y, Li S, Chen N, Yu YA, Szalay AA, Fong Y: Real-time intraoperative detection of melanoma lymph node metastases using recombinant vaccinia virus GLV-1h68 in an immunocompetent animal model. Int J Cancer 2009, 124:911-918.

52. Gentschev I, Donat U, Hofmann E, Weibel S, Adelfinger M, Raab V, Heisig M, Chen N, Yu YA, Stritzker J, Szalay AA: Regression of human prostate tumors and metastases in nude mice following treatment with the recombinant oncolytic vaccinia virus GLV-1h68. J Biomed Biotechnol 2010, 2010:489759.

doi:10.1186/1479-5876-10-167

Cite this article as: Wang et al:: Oncolytic vaccinia virus GLV-1h68 strain shows enhanced replication in human breast cancer stem-like cells in comparison to breast cancer cells. Journal of Translational Medicine 2012 10:167.

\section{Submit your next manuscript to BioMed Central and take full advantage of:}

- Convenient online submission

- Thorough peer review

- No space constraints or color figure charges

- Immediate publication on acceptance

- Inclusion in PubMed, CAS, Scopus and Google Scholar

- Research which is freely available for redistribution 